\title{
ALA Representatives at Academic Ceremonies
}

On Dec. 9 Richard G. Elliott represented ALA at the inauguration of Johnathan Bert Barnes as president of the College of Idaho. On Jan. 26 at the inauguration of Paul Francis Geren as president of Stetson University Martha Marie Berhel represented ALA; Evan Farber represented ALA and ACRL at the National Conference on Emerging Universities and National Concerns at Ball State University on Feb. 7-8.

At the inauguration of Hugh Morris Gloster as president of Morehouse College on Feb. 17, Mrs. Virginia Lacy Jones represented ALA; W. Stanley Hoole was the representative at the inauguration of Harold N. Stinson as president of Stillman College on Mar. 9. At the inauguration of John Arthur Peoples, Jr. as president of Jackson State College (Miss.) on Mar. 9 Mary O'Bryant represented ALA.

G. Flint Purdy was the ALA representative at the inauguration of Robben Wright Fleming as president of the University of Michigan on Mar. 11; Richard J. Beck, at the inauguration of Glenn Terrell as president of Washington State University, Pullman, on Mar. 17; and Hugh A. Brown, at the inauguration of Lloyd Drexell Vincent as president of Angelo State College (Tex.) on Mar. 24-25.

On Mar. 27, ALA was represented by Eleanor MeCann at the inauguration of Wesley Wentz Posvar as chancellor of University of Pittsburgh; on Mar. 28 by John P. McDonald at the inauguration of Arthur C. Banks, Tr., as president of the Greater Hartford Community College. At the inauguration of Robert Edwin Kennedy as president of the California State Polytechnic College on Apr. 3, Donald C. Davidson represented ALA; and at the inauguration of Norman A. Wiggins as president of Campbell College on Apr. 6, Jerrold Orne was the ALA representative.

Hardin Craig, Jr., represented ALA at the dedication of the library addition at the University of Houston on Apr. 10. Herbert Poole was the ALA representative at the inauguration of James Ralph Scales as president of Wake Forest University on Apr. 11; Benjamin B. Richards, at the inauguration of Earland Irving Carlson as president of Westminster College on Apr. 19; and Kenneth J. LaBudde, at the inauguration of Peter $\mathrm{H}$. Armacost as president of Ottawa University (Kans.) on Apr. 21 .

At the inauguration of Hawthorne Clough Evans, Jr., as president of Lees-McRae College on Apr. 22 William L. Eury was the ALA representative. Mark Gormley represented ALA at the inauguration of John T. Middaugh as president of Carroll College on Apr. 27; also on Apr. 27, James V. Jones represented ALA at the installation of Robert Warren Morse as president of Case Western Reserve University. At the inauguration of Martha E. Peterson as president of Barnard College on Apr. 29 Richard Logsdon was the ALA representative; at the inauguration of Paul Russell Anderson as president of Temple University on May I Richard L. Snyder represented ALA; and at the inauguration of Marvin Banks Perry, Jr., as president of Goucher College on May 3 John H. Berthel represented ALA.

At Cornell College's inauguration of Samual Enoch Stumpf as president on May 4 Dale M. Bentz represented ALA, and Nada Vujica was the representative at the dedication of the Learning Resources Center of Marywood College on that date. Carson W. Bennett represented ALA at the dedication of Tiffin University library on May 4. James F. Holly represented ALA at the inauguration of $\mathrm{Mal}$ colm Charles Moos as president of the University of Minnesota on May 9. On May 10 John R. Russell represented ALA at the inauguration of E. K. Fretwell, Jr., as president of the State University of New York College at Buffalo; on May 11, David Estes, at the inauguration of Frederick Corbet Davison as president of the University System of Georgia; and also on May 11, Mrs. William Bryan, at the inauguration of Samuel $\mathbf{E}$. Braden as president of Illinois State University, Normal. On May 17, Frayne Anderson represented ALA at the inauguration of Harry Pitkin Bowes as president of General Beadle State College; on May 18 , Sister Bernard Joseph, at the inauguration of George B. Erbstein as president of Ulster County Community College (N.Y.); on May 23, Lewis F. Stieg, at the inauguration of Charles Johnston Hitch as president of the University of California, Berkeley; and on May 24, Sister Marie Jean at the inauguration of Rhoten A. Smith as president of the University of Northern Illinois.

\section{TAUBER HONORED}

Maunice F. Tauber, professor in the school of library service, Columbia University, was awarded a Distinguished Service Award on the dedication of the Findlay College library, Findlay, Ohio, for "outstanding contributions to higher education, as a teacher, writer, librarian, critic and leader in the science of library service and 'partner in learning' to untold numbers, May 10, 1968." Dr. Tauber was senior programer for the library building, and presented a paper on the issue of "Partners in Learning." 


\section{For college libraries facing the problems of rapid expansion and change:}

\section{The Total Library Service}

Book Selection and Supply: Bro-Dart distributes books of all publishers, domestic and foreign, including all titles from Books for College Libraries (A.L.A.) and the new Junior College Library Collection (Bro-Dart Foundation) and Choice's Opening Day Collection. Paperbacks are supplied hard-bound (by our own bindery) if desired.

Book "Approval" Program: This unique new plan enables college libraries to become aware of, and actually acquire, all new books published in any specialized pre-determined fields. Colleges have an opportunity to examine, on approval, all books shipped and keep those desired for their collection. LC cards are included as an option. This program saves time, money and paperwork, while keeping colleges constantly updated on new publications of interest.

Books for Publication Date Shelving: This is an ideal program if your library requires current fiction and popular non-fiction (including that material normally covered by reviewing services). You select one month prior to publication from an annotated list of titles and receive them ready for circulation by publication date, when interest is greatest. Books in this program can also be leased under our McNaughton Plan.

Cataloging and Processing: Bro-Dart's custom cataloging service was established to provide the Library with (a) both the efficiency and economy of coordinated and centralized book cataloging and processing, (b) the professional skill of experienced librarians, and (c) the vital help often needed by the library to solve problems of supervision, personnel replacement, fluctuating workloads, and supply storage. The service is available on either a temporary or long term basis. Library of Congress cataloging utilizing either the Library of Congress or Dewey Classification is available. An original cataloging service is provided where Library of Congress cataloging is unavailable.

The Computer Book Catalog: In addition to its use as a union catalog for a library system, the Book Catalog is important in the expansion of library service into various departments and areas of instruction within a single institution. Its ease of use and ready acceptance by library users further recommend the Book Catalog for consideration.

Bro-Dart's Library Computer Center produces, prints and binds Book Catalogs within its own facilities. They offer colleges a variety of available programs and a large and growing data base of machine readable cataloging which accommodates cataloging information being developed by the Library of Congress in its MARC Program.

Circulation Systems : Of our many Bro-Dart developed book charging systems, Sysdac is especially attractive to college libraries using student identification cards. Bro-Dart has also devised a system which allows an economical progression from the simplest hand-charging to the most sophisticated computer circulation system without interim conversions.

Reclassification: If you are about to reclassify your collections, we are in a unique position to assist you in all or part of the complex work of reclassification, and to propose ways in which automation can accomplish this.

Furniture: We design and manufacture several lines of furniture in our own plants, specifically for college libraries.

Supplies: Immediately available: all the supplies you need to protect books and periodicals; to repair books; or for circulation systems; a full range of printed forms and other supplies for library maintenance and management.

Consultation: Whether you are faced with renovation, expansion, or the planning of an entire new library, our professional staff-with experience in helping thousands of libraries - is equipped to undertake a study of your total needs.

If there is anything more we can tell you, please write, without obligation: Department:

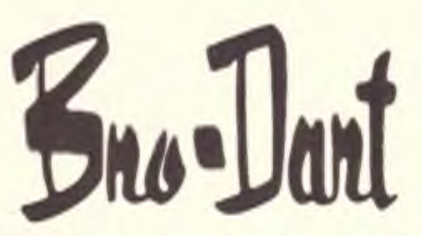

P.0. Box 923, Williamsport, Pa. 17704

Williamsport - Newark • Los Angeles • Brantford, Ontario

The Complete Library Source 